\title{
Dynamic Relationship between China's Inward and Outward Foreign Direct Investments
}

Jinghua Ou, Pan Wang, Jing Zhang, Shujie Yao*

Jinghua Ou (oujinghua@cqu.edu.cn) is lecturer of economics, Chongqing University, China; Pan Wang (wangpan110@hotmail.com) investment executive, Agricultural Bank of China, Zhejiang Branch; Jing Zhang (j.zhang@nottingham.ac.uk) lecturer of Chinese Studies, University of Nottingham, UK; Shujie Yao (*corresponding author, shujie.yao@nottingham.ac.uk) professor of economics, School of Economics and Business Administration, Chongqing University, China; and School of Contemporary Chinese Studies, University of Nottingham, UK. 


\title{
Dynamic Relationship between China's Inward and Outward Foreign Direct Investments
}

\begin{abstract}
This paper studies the dynamic relationship of China's inward and outward foreign direct investments (FDI). It first identifies the key determinants of China's outward FDI (OFDI) in 172 host countries during 2003-09 using a partial stock adjustment model. It finds strong evidence of dynamic adjustment in China's OFDI stock with an agglomeration effect. The dynamic adjustment and agglomeration effects are stronger in "high-tech" countries than in "low-tech" ones but indifferent in host country's resource endowments and income levels. The empirical results suggest that there exists a substantial adjustment cost in China's OFDI and that China's existing OFDI stock can gradually adjust towards its long term equilibrium level, which is not only greater but also more volatile than the actual stock. Of particular interest is that we find a strong and positive relationship between lagged inward FDI (IFDI) and contemporaneous OFDI, implying that capital outflow from China has been partially induced by the countries which have invested in China.
\end{abstract}

Keywords: foreign direct investment, dynamic adjustment, agglomeration effect, partial stock adjustment, China

JEL Classification: F21; O53 


\section{Introduction}

The geo-economic pattern of foreign direct investments (FDI) has changed significantly since 2000 as developed countries' domination has been seriously challenged by the emerging and transition economies. The share of global FDI accounted for by the developed world declined from over $90 \%$ in the end of the $20^{\text {th }}$ century to only $65 \%$ by 2012 .

Multinational enterprises (MNEs) in developed countries took a "wait-and-see" approach or divested their assets from host countries (UNCTAD 2013). In contrast, MNEs from emerging and transition economies took an aggressive approach in overseas expansion, led by the socalled BRICS economies (Brazil, Russia, India, China and South Africa).

Developed-country MNEs usually combine their ownership and internalisation advantages with location advantage to minimise the overall cost of operation (Dunning et al. 2001). Such conventional FDI theory only partially explains the internationalisation of emerging economy MNEs (EMNEs). Recent theoretical research suggests that EMNEs use OFDI (outward FDI) as a springboard to acquire strategic resources and to overcome institutional and market constraints at home (Luo and Tung, 2007).

There have been a number of empirical studies on the determinants or motivations of EMNEs' overseas expansion (Makino et al. 2002; Yamakawa et al. 2008), particularly those based on Chinese experiences (Buckley et al. 2007; Cheung and Qian 2009; Zhang and Daly, 2011; Kolstad and Wiig, 2012; Ramasamy et al. 2012). However, these studies investigate the attraction factors of OFDI from China and other emerging economies in a static framework. None of them considers the dynamic adjustment of OFDI stock towards its long term equilibrium.

This paper aims to fill this literature gap through investigating the dynamic adjustment 
process of China's OFDI in 172 countries during 2003-09. China is selected of interest because it has become the largest investor among all the developing countries and the third largest investor in the world (UNCTAD 2013). We construct a partial stock adjustment model proposed in Cheng and Kwan (2000), which enables us to examine the dynamic adjustment effect of OFDI and to restore its unobservable equilibrium stock value. Estimating the equilibrium OFDI stock and comparing it with the actual stock can help us understand China's OFDI behaviour from a new dimension.

As China has become one of the largest recipients as well as one of the largest investors of foreign capital in the world, it is an ideal candidate to study the intrinsic relationship between IFDI (inward FDI) and OFDI. However, the empirical evidence in the OFDI literature is limited. This paper considers the impact of IFDI stock on China's OFDI in the host countries. Other control variables include bilateral trade, market size, GDP growth, income level, openness, institution quality, inflation, resource endowment and technology of the host countries. It further investigates if the effects of these factors vary with some host country characteristics, such as technology, resources and incomes. A system generalised method of moments (system GMM) technique is used for estimation.

The rest of the paper is organised as follows. Section 2 briefly reviews China's OFDI in recent years. Section 3 reviews the relevant literature on the location choice of China's OFDI. Section 4 presents data, methodology and the empirical model of partial adjustment in OFDI. Section 5 presents and discusses the empirical results. The final section concludes.

\section{Development of China's OFDI}

China's OFDI has expanded substantially since the country entered to the World Trade Organization (WTO) in 2001 and the launch of the 'Go Global' strategy in 2002. China has 
established an OFDI policy system including a series of promotion measures and monitoring policies to support its MNEs investing overseas (Luo et al. 2010). During the 2003-08 period, the average annual growth rate of China's OFDI was $73 \%$ compared to the world average of $29 \%$ (UNCTAD data base).

Although the world financial crisis significantly cut down the scale of global investments, China's OFDI still achieved an annual growth of 11\% in the crisis period 2009-12 (Figure 1).

Figure 1: China's OFDI Flow and Stock and IFDI Flow (US\$ current prices in billions)

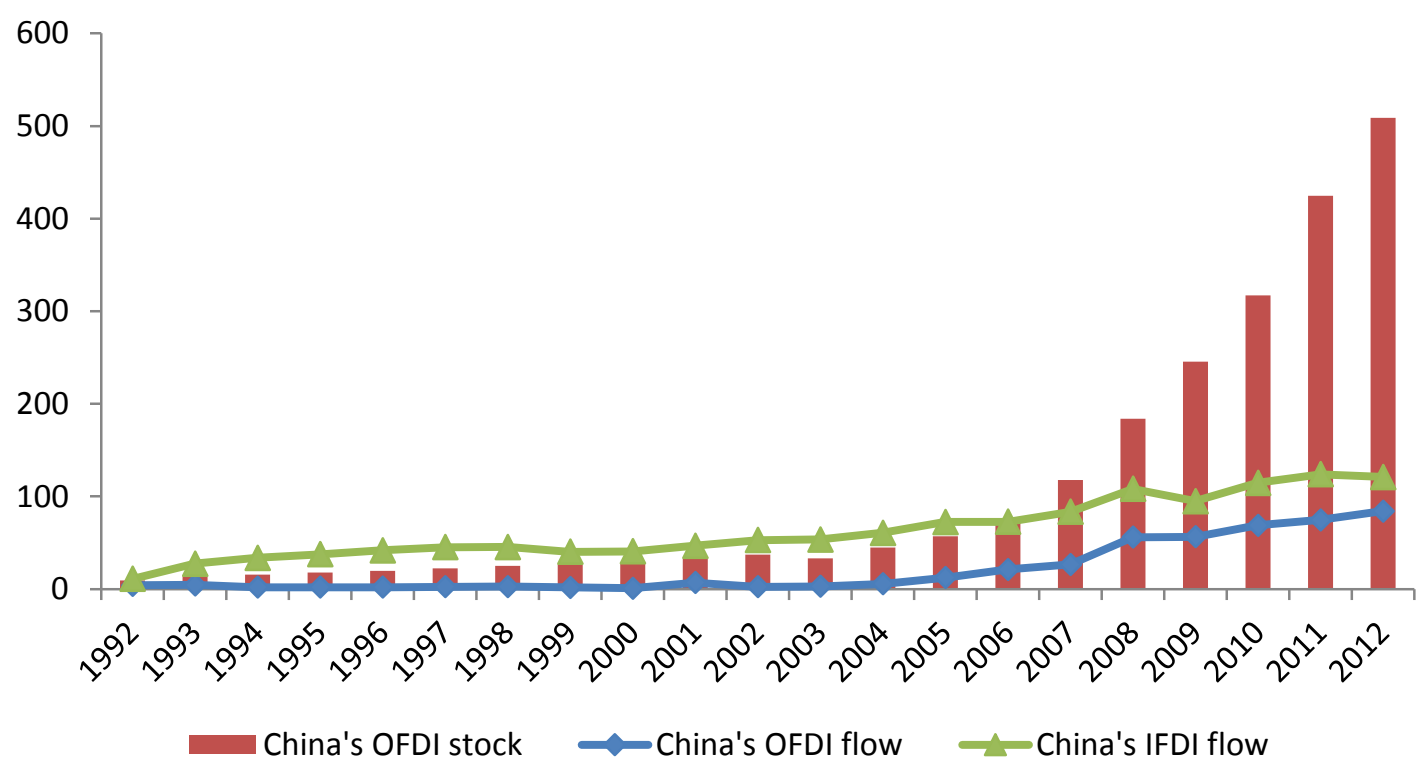

Source: UNCTAD Statistics, http://unctadstat.unctad.org/EN/.

Yao and Sutherland (2009), Yao et al. (2010) and Xiao and Sun (2005) have pointed out that a distinctive feature of China's emergence as a major global investor is the country's national "Go Global" strategy. Selected large state-owned enterprises (SOEs) are deployed as investment vehicles supported with a soft-budget constraint and easy bank credits to realise the country's overseas investment interests, such as securing a long-term and stable supply of natural resources at reasonable prices. 
China has only become a large FDI source country very recently, but it has long been acknowledged as an important FDI recipient thanks to its opening up policy adopted in 1979. It has been the top host country of IFDI in the developing world since the late 1990s and one of the three largest host countries in the world since 2005 (UNCTAD 2007).

China has invested in both the developed and developing economies with a high concentration in Asia, particularly Hong Kong. By the end of 2012, over two-thirds of China's total OFDI went to Asia, with Hong Kong accounting for 57.6\% (Table 1).

Table 1 Key Destinations of China's OFDI (\$ billions), end of 2012

\begin{tabular}{|c|c|c|c|}
\hline & OFDI Stock & Share \% & Rank \\
\hline Total & 531.9 & 100.0 & \\
\hline Asia & 364.4 & 68.5 & \\
\hline Hong Kong, China & 306.4 & 57.6 & 1 \\
\hline Indonesia & 3.1 & 0.6 & 13 \\
\hline Japan & 1.6 & 0.3 & 18 \\
\hline Macao, China & 2.9 & 0.6 & 15 \\
\hline Singapore & 12.4 & 2.3 & 6 \\
\hline Republic of Korea & 3.1 & 0.6 & 14 \\
\hline Africa & 21.7 & 4.1 & \\
\hline Nigeria & 2.0 & 0.4 & 17 \\
\hline South Africa & 4.8 & 0.9 & 10 \\
\hline Europe & 37.0 & 7.0 & \\
\hline United Kingdom & 8.9 & 1.7 & 7 \\
\hline Germany & 3.1 & 0.6 & 12 \\
\hline France & 4.0 & 0.7 & 11 \\
\hline Russia & 4.9 & 0.9 & 9 \\
\hline Latin America & 68.2 & 12.8 & \\
\hline Cayman Islands & 30.1 & 5.7 & 3 \\
\hline Virgin Is. (E) & 30.9 & 5.8 & 2 \\
\hline North America & 25.5 & 4.8 & \\
\hline Canada & 5.1 & 0.9 & 8 \\
\hline United States & 17.1 & 3.2 & 4 \\
\hline Oceania & 15.1 & 2.8 & \\
\hline Australia & 13.9 & 2.6 & 5 \\
\hline
\end{tabular}

Notes: The values of OFDI stock reported in China Statistical Yearbook are slightly different from those reported in UNCTAD Statistics.

Sources: China Statistical Yearbook (NBS, 2013).

Tax heavens, such as the British Virgin and Cayman Islands are also two of the most attractive locations for China's OFDI. Developed countries, such as the US, Australia, 
Singapore, Canada and the member states in the EU, have also become popular host countries of Chinese capital. Other destinations of China's OFDI include the developing countries in Africa and Latin America. It is interesting that countries with high political risk, for example, Sudan, are important hosts of Chinese capital (accounting for $0.2 \%$ ). In addition, it is notable that some of the economies listed in Table 1 are also the top sources of China's IFDI, such as Hong Kong, Singapore, Korea, Japan, the US, the UK, Germany and France.

Table 2 shows the sectoral distribution of China's OFDI stock. More than $70 \%$ of the Chinese capital flowed into the services industries, such as leasing and business services, financial intermediation; wholesale and retail trades, and transport, storage and post. A few Chinese firms have invested in scientific research and the information technology industries. The sectoral distribution of China's OFDI suggests that the country's MNEs may be regarded as market or strategic asset seekers. Resource exploration related industries (mining; production and supply of electricity, gas, heat, and water) and agriculture also take a significant share of the OFDI stock, suggesting that some Chinese firms are natural resources seekers.

The sustained growth of China's OFDI motivates us to examine whether it has selfperpetuating growth, that is to say, whether existing OFDI stock has a positive feedback on future investment and hence adjusts itself towards a long term equilibrium. The similar trends in IFDI and OFDI, as well as the destinations of China's OFDI, encourage us to examine whether cumulative FDI from one country to China has also promoted Chinese MNEs to invest in that country later on. Finally, the distributions of China's OFDI across countries and sectors make it possible and interesting to examine how it may have been affected by host country characteristics. 
Table 2 Sectoral distribution of China's OFDI stock ( \$ billions), end of 2012

\begin{tabular}{lcc}
\hline & OFDI stock & $\%$ \\
\hline Total & $\mathbf{5 3 1 . 9}$ & $\mathbf{1 0 0 . 0}$ \\
Leasing and Business Services & 175.7 & 33.0 \\
Financial Intermediation & 96.5 & 18.1 \\
Mining & 74.8 & 14.1 \\
Wholesale and Retail Trades & 68.2 & 12.8 \\
Manufacturing & 34.1 & 6.4 \\
Transport, Storage and Post & 29.2 & 5.5 \\
Construction & 12.9 & 2.4 \\
Real Estate & 9.6 & 1.8 \\
Production and Supply of Electricity, Heat, Gas and Water & 9.0 & 1.7 \\
Scientific Research and Technical Services & 6.8 & 1.3 \\
Agriculture, Forestry, Animal Husbandry and Fishery & 5.0 & 0.9 \\
Software and Information Technology & 4.8 & 0.9 \\
Service to Households, Repair and Other Services & 3.6 & 0.7 \\
Culture, Sports and Entertainment & 0.8 & 0.2 \\
Hotels and Catering Services & 0.8 & 0.1 \\
Education & 0.2 & 0.03 \\
Management of Water Conservancy, Environment and & 0.1 & 0.01 \\
Health and Social Service & 0.1 & 0.01 \\
\hline
\end{tabular}

Notes: The values of OFDI stock reported in China Statistical Yearbook are slightly different from those reported in UNCTAD Statistics.

Sources: China Statistical Yearbook (NBS, 2013). 


\section{Literature Review}

\subsection{Determinants of OFDI}

Some existing empirical studies suggest that market and asset seeking are the main motivations of Chinese MNEs going abroad. Due to data availability, earlier studies have used the total amount of foreign exchange approved by the government as a measurement of Chinese OFDI. Buckley et al. (2007) find that Chinese OFDI was attracted by market size and natural resources of host countries during 1984-2001. The results also suggest that Chinese OFDI is associated with high political risks in and cultural proximity to host countries. Cheung and Qian (2009) also find evidence of both market and resource seeking motivations of Chinese OFDI during 1991-2005. They find that Chinese exports to developing countries and foreign exchange reserves induce OFDI and Chinese capital displays different types of agglomeration behaviour across developed and developing economies.

Using actual OFDI flows during 2003-09, Zhang and Daly (2011) find Chinese OFDI is positively related with international trade, market size, GDP growth, openness and resource endowment of host countries. Kolstad and Wiig (2012) find Chinese OFDI is attracted to large markets and to countries with a combination of rich natural resources and poor institutions.

Ramasamy et al. (2012) combine the data of public listed Chinese MNEs and that of host countries during 2006-08 and use the frequency count of Chinese FDI projects in the host country as a measurement of OFDI. The findings suggest that state-controlled firms are attracted to countries with rich natural resources and unstable political environments, whereas private firms are more market seeking oriented. 
The above studies all investigate the factors in the host countries that attract OFDI from China. However, these studies model Chinese OFDI in a comparative static framework. They do not take into account the agglomeration effect that considers the self-perpetuating growth of OFDI. When examining the determinants of IFDI stock, Cheng and Kwan (2000) states that observed FDI stock has a positive feedback on future investment even without the influence of other determinants, triggering the gradual adjustment from the actual stock towards its equilibrium level. Investment inertia takes time to adjust, and the adjustment inevitably incurs costs. In addition, these determinants change over time so the equilibrium level is continuously changed. Similarly, Chinese OFDI may also face this dynamic adjustment and adjustment cost but this has largely been ignored in the existing literature.

\subsection{IFDI and OFDI}

Exiting studies on FDI usually concentrate on inward or outward FDI individually. The relationship between IFDI and OFDI has received some, but limited attention in the literature, although this is largely unexplored except a few descriptive studies (Sauvant 2011; Sauwant et al. 2011; Liu et al. 2005; Katherin and Cornelia 2007). According to investment development path theory (Dunning, 1993), a country only has IFDI at the first stage of development. OFDI starts in the second stage and gets stronger in the third stage with activities related to market and resources seeking. At the fourth stage of development, OFDI is even stronger and with high levels of $R \& D$ capacities. The evolution shows that OFDI occurs once the country reaches a threshold growth point and when local firms have acquired firm-specific advantages that allow them to engage in OFDI. IFDI from developed countries provides channels for EMNEs to acquire technology and other firm specific know-how (Fu and Zhang, 2011). Firstly, advanced technologies can be transferred to host country firms within the joint ventures through imported equipment and labour training. Secondly, technologies are transferred through horizontal spillovers to other firms in the same industry 
through demonstration and labour turnover. Thirdly, vertical sprillovers occur within the value chain through linkages with suppliers, distributors and customers. Finally, competition effect will force firms to innovate to maintain competitive advantages.

In terms of empirical studies, Wei (1995), Woo (1995) and Dees (1998) find IFDI affect economic growth in China. However, there is mixed evidence for the effect of IFDI on productivity and innovation capabilities of local Chinese firms. Buckley et al. (2002) find foreign invested firms generate technological spillovers to Chinese firms. Hu and Jefferson (2002) find negative short-run spillover effect of FDI in general but its long-run effect depends on other factors, such as sector, FDI sharing ownership of local firms, competitiveness of local firms, and source country of FDI. Fu and Gong (2011) find FDI contributes to static industry capabilities but its $R \& D$ activities have negative effect on technological change of local Chinese firms. These studies, to some extent, provide evidence of the indirect linkage between IFDI and OFDI.

Li et al. (2012) provides evidence of direct linkage between IFDI and OFDI associated knowledge transfer. They argue that emerging countries like China use OFDI as a substitute for acquiring knowledge associated with IFDI. Therefore, the higher the level of IFDI in an industry, the lower positive effect of the host country technology advantage in that industry and hence decreases emerging markets to invest in foreign countries for knowledge-seeking.

To explain the effect of IFDI on OFDI, a couple of studies in business internationalization look at the impact of business network on EMNEs overseas investment. Ning and Sutherland (2012) argue that, as latecomers of the global production network, EMNEs obtain knowledge of foreign markets and enhance capabilities through being the suppliers of mature MNEs (through IFDI) in their domestic markets. Then EMNEs are able to engage in OFDI at later stages, usually based on their supply relationship with their foreign partners. They find a 
number of Chinese firms set subsidiaries in other countries to meet the demands of their nonChinese MNEs in these markets. Through the close relationships with these non-Chinese MNEs, many Chinese-MNEs have internationalized further and become successful MNEs. Hertenstein et al. (2015) find that OFDI strategies of Chinese MNEs in the auto components industry are shaped by sub-contracting supply relationships established through prior IFDI. Prior IFDI by MNEs from developed countries have important home country effect on the location choices, strategic asset seeking orientation and pace of internationalization. Within business networks, the insidership will help firms reduce uncertainty, increasing learning, build trust and exploit more opportunities, and in turn, increase the levels of network commitment, all considered crucial for internationalization process. Hertenstein et al. (2015) interviewed 5 Chinese auto component suppliers, all of which had significant business engagement with other MNEs invested in China prior to investing overseas. Their OFDI projects were oriented to enhancing commitment to and benefits from their relationships. They usually chose foreign locations close to their MNE partners. It explains why some Chinese MNEs invest in physically distant developed countries at the early stage of internationalization. They acquire technologies for further commitment to the network positions, and in turn their commitment to the network speeded up their expansion in scale, international geographical coverage, and complexity of products.

There have been few economic studies in this area except the following. Apergis (2009) conducts simple panel cointegration and panel causality tests on the association between OFDI and IFDI, using a dataset for 35 countries in 1981-2004. The results suggest that OFDI has a significant long-run relationship with IFDI, indicating that OFDI will enhance growth of an economy through the attraction of IFDI which will in turn move the economy onto higher growth levels. Mo (2014) links the IFDI-OFDI nexus with entrepreneurial behaviour in ten industries over the period 2003-2012 in China. The findings show that IFDI flows is 
negatively associated with OFDI flows, reflecting that China is entering a mid-late period of investment development path with a deceasing trend of IFDI and increasing growth of OFDI in the observed period. The results also suggest that IFDI affects China's entrepreneurship and entrepreneurial behaviour affects OFDI. However, Mo (2014) does not consider other variables that may have impact on OFDI except IFDI and entrepreneurial indices so that missing variable bias might occur in the regression models. Therefore, prior IFDI is important for Chinese firms to gain experience and knowledge, understand foreign markets, establish business networks, and enhance entrepreneurship, all considered as preconditions for taking OFDI projects. It is reasonable to expect that China's prior IFDI may have influence on its OFDI. However, the evidence providing direct evidence of IFDI-OFDI relationship is still limited.

This paper aims to fill the two gaps in the FDI literature by examining the dynamic adjustment effect of OFDI and its relationship with IFDI in China.

\section{Methodology, data and model}

The partial stock adjustment model was developed by Chow (1967). Cheng and Kwan (2000) and Campos and Kinoshita (2003) have adopted this model when investigating the IFDI path towards an equilibrium stock in China and transition economies, respectively. Following these studies, we assume that China's OFDI stock (COFDIS) adjust towards its equilibrium $\left(C O F D I S^{*}\right)$ according to the process expressed in Equation (1).

$\frac{d C O F D I S_{i t}}{d t}=\alpha C O F D I S_{i t}\left(\ln \operatorname{COFDIS}_{i t}^{*}-\ln \operatorname{COFDIS}_{i t}\right)$

Equation (1) suggests that the rate of growth of OFDI stock depends on two factors. The first factor is the quantity of existing stock $\left(C O F D I S_{i t}\right)$, which has a positive "self-reinforcing" 
effect, meaning that the more China invests in a host country, the more it will continue to do so in the future. This effect resembles the agglomeration effect of FDI (Head and Ries 1996). The second factor is the difference between the equilibrium level $\left(C O F D I S_{i t}{ }^{*}\right)$ and the actual stock $\left(C O F D I S_{i t}\right) . \alpha$ is the adjustment speed, taking values between 0 and 1 . A higher value of $\alpha$ reflects a higher adjustment speed and a smaller adjustment cost, or vice versa. The model shows that the self-reinforcing effect diminishes when COFDIS $S_{i t}$ approaches the equilibrium level. It implies that China's overseas investment adjusts gradually rather than instantaneously because investment inertia takes time to adjust towards its long term equilibrium. The installation of new investment is slowed down by a convex adjustment cost whose marginal value increases with capital stock.

Since $\frac{d C O F D I S_{i t}}{C O F D I S_{i t}}=d \ln C O F D I S_{i t}$, equation (1) can be written as

$\frac{d \ln C O F D I S_{i t}}{d t}=\alpha\left(\ln C O F D I S_{i t}^{*}-\ln C O F D I S_{i t}\right)$

We approximate $\frac{d C O F D I S_{i t}}{d t}=d \ln C O F D I S_{i t}-\ln C O F D I S_{i t-1}$, and $C O F D I S_{i t}$ by $C O F D I S_{i t-1}$. Substituting the above relations into Equation (2) with re-arrangement, we have Equation (3).

$\ln$ COFDIS $_{i t}=(1-\alpha) \ln C O F D I S_{i t-1}+\alpha \ln C O F D I S_{i t}^{*}$

The actual OFDI stock $\left(\ln C O F D I S_{i t}\right)$ is presented as a weighted value of its previous stock $\left(\ln C O F D I S_{i, t-1}\right)$ and equilibrium value ( $\left.\ln C O F D I S_{i t}^{*}\right)$. Campos and Kinoshita (2003) indicate that a positive and less than unity $\alpha$ implies stability.

The equilibrium stock is assumed to be a function of certain variables. 
$\ln C O F D I S_{i t}^{*}=\lambda^{\prime} \bar{X}_{i t}+\mu_{i}+v_{t}+\varepsilon_{i t}$

$X_{i t}$ is a vector of explanatory variables; $\mu_{\mathrm{i}}$ captures all the unobserved country-specific effects that are time unvarying; $v_{\mathrm{t}}$ refers to time-specific effects; and $\varepsilon_{i t}$ is a random disturbance. Equation (3) implies that equilibrium OFDI stock solely depends on the change in its determinants, and is not affected by the adjustment cost. Integrating equation (4) into equation (3), a partial stock adjustment model is rewritten in equation (5).

$\ln \operatorname{COFDIS}_{i t}=(1-\alpha) \ln \mathrm{COFDIS}_{i t-1}+\beta^{\prime} \bar{X}_{i t}+\phi_{i}+\varphi_{t}+\xi_{i t}$

where $\alpha \lambda^{\prime}=\beta^{\prime}$ and $\alpha \mu_{i}+\alpha v_{t}+\alpha \varepsilon_{i t}=\phi_{i}+\varphi_{t}+\xi_{i t}$.

The final model can be written as:

$$
\begin{aligned}
\ln \text { COFDIS }_{i t} & =\beta_{1} \ln \text { COFDIS }_{i t-1}+\beta_{2} \ln \text { CIFDIS }_{i t-1}+\beta_{3} \ln \text { Imports }_{i t-1}+\beta_{4} \ln \text { RGDP }_{i t} \\
& +\beta_{5} \text { RGDP__rowth }_{i t}+\beta_{6} \ln \text { RGDPPC }_{i t}+\beta_{7} \ln \text { Exports }_{i t}+\beta_{8} \ln \text { Openness }_{i t} \\
& +\beta_{9} \text { Governance }_{i t}+\beta_{10} \text { Inflation }_{i t}+\beta_{11} \text { Resouces }_{i t}+\beta_{12} \text { Technology }_{i t} \\
& +\phi_{i}+\varphi_{t}+\xi_{i t}
\end{aligned}
$$

where $i$ and $t$ denote host country $i$ and year $t$, respectively.

$\operatorname{lnCOFDIS} S_{i t-1}$ is China's OFDI stock lagged by one year in country $i$ at time $t-1$. OFDI stock is commonly used in empirical studies to represent the agglomeration effect (Wheeler and Mody, 1992; Barrell and Pain, 1999; Cheung and Qian, 2009; Wagner and Timmins, 2009). Cheng and Kwan (2000) argue that the implications of including lagged FDI stock were threefold. Firstly, it functions as an agglomeration effect, generating 'positive feedback' and externalities so that further investments would be self-reinforced. Secondly, it is associated with an adjustment process, as illustrated in the above partial stock adjustment model. 
Thirdly, it is helpful to calculate the unobservable equilibrium stock. A positive and less than unity $\beta_{1}$ supports the self-reinforcement effect and the dynamic adjustment of China's OFDI.

According to the literature, prior IFDI might have influence on OFDI and the home country effect is important for the OFDI location choice, we have $\operatorname{lnCIFDIS} S_{i, t-1}$ which means the previous stock of IFDI from country $i$ at time $t-1$ in China. There are two reasons to use the lagged stock value to capture potential externality. Firstly, Driffield and Love (2003) also argue that the stock of IFDI rather than its flow is more likely to include cumulative knowledge. Similarly, it can be assumed that IFDI stock takes time to generate externality (including knowledge, experience, business networks establishment, entrepreneurship etc.) and it also takes time for IFDI to have an effect on OFDI. There are many restrictions to prohibit this externality generation. However, they diminish over time. Therefore, IFDI stock is more likely to generate positive externality to promote OFDI. Secondly, the lagged value is introduced to avoid any spurious correlation. Oulton (1996) and Driffield and Love (2003) demonstrate that using lagged IFDI can tightly define spillovers. It is less likely that contemporaneous residuals will relate to previous IFDI and hence the estimation is not spurious. If we use the contemporaneous value of IFDI stock, unobserved factors left in the error term may simultaneously affect contemporaneous IFDI and OFDI. They may take the form of a common shock, though. For example, the liberalisation of foreign economic policy may simultaneously stimulate IFDI and OFDI. Overall, one-year lagged values of IFDI stock are introduced to present the correlation between China's IFDI and OFDI. However, we also noted that the lagged IFDI stock variable is an aggregate measure of IFDI which does not allow us to understand the mechanisms through which the effect takes place. It does not allow us to look at the effect which might vary across, for example, sector and entry mode of IFDI. $\beta_{2}$ is expected to be positive, signifying a positive association and implying that China's 
previous stock of IFDI promotes its contemporaneous OFDI stock. lnImportst-1 is the value of imports lagged by one period from host countries. It is added to control the effect of previous IFDI on contemporaneous OFDI. As another potential source to generate externality, the lagged value is also introduced to avoid spurious correlation.

The remaining control variables are similar to those used in Yao and Wang (2014). Real GDP $(\ln R G D P)$ and annual growth rate of real GDP (RGDP_Growth) represent economic masses (Yeaple, 2003; Hanson et al., 2001; Buckley et al., 2007). Larger GDP and faster economic growth imply bigger markets and more opportunities. Therefore, positive coefficients for these two control variables are expected.

Real GDP per capita ( $R G D P P C)$ capture the income level of the host countries and its impact on China's OFDI can be ambiguous. On the one hand, income may reflect the quality of domestic labour. A high income usually implies high labour productivity and has a positive effect on China's OFDI. On the other hand, it also reflects the cost of operation in the host country. High income implies high cost and has a negative effect on China's OFDI. The net effect of host country income depends on the interaction between its positive effect as a measurement of labour productivity and its negative effect as wages cost.

Bilateral exports (Exports) could be either substitution or complementarity to OFDI. Internalisation theory (Buckley and Casson, 1976) and horizontal FDI theory (Markusen, 1984) support a substitution relationship, while vertical FDI theory (Helpman, 1984) sustains a complementary relationship. Empirically, it has been examined by using both aggregate and disaggregate data at country level (Grubert and Mutti, 1991), industry level (Brainard, 1997), firm level (Head and Ries, 2001) and product level (Blonigen, 2001). Given China's exportoriented economy and the close relation between OFDI and exports, a positive coefficient is expected. 
The effect of trade openness (Openness) is also controversial. On the one hand, higher level of openness in the host country would attract more foreign investment and has a positive effect on OFDI. On the other hand, it is negatively associated with trade barriers of the host country. If China were to conduct OFDI in a high trade barriers country because of the 'tariffjumping' motivation, this may have a negative effect on OFDI.

Governance quality of the host country (Governance) is measured by the World Bank's Index of Control of Corruption published in The Worldwide Governance Indicators (Habib and Zurawicki, 2002) and the Political Risk Index from International Country Risk Guide (ICRG). A higher value implies a lower degree of corruption, and hence better governance. The effect of governance on FDI is ambiguous. On the one hand, good governance reduces the risks of uncertainty and make the host country more attractive (Globerman and Shapiro, 2002; Blonigen, 2005; Cole, et al. 2009). On the other hand, a number of studies suggest that China is more experienced in dealing with an opaque business environment than its Western rivals (Child and Rodrigues, 2005; Mock et al., 2008) so Chinese firms tend to be attracted to countries with poor institutions (Buckley et al. 2007; Kolstad and Wiig, 2009).

The impact of inflation (Inflation) on Chinese OFDI is also included, similar to Kolstad and Wiig (2009). High inflation would discourage FDI because high economic instability and low real profit would limit market-seeking FDI (Buckley et al. 2007). High inflation devalues the local currency and discourages export-oriented FDI as well. Therefore, a negative sign is expected.

Host country's overall natural resource endowment (Resources) examines whether China's OFDI is motivated by natural resource-seeking. Following Cheung and Qian (2009) and Zhang (2009), the share of fuels, ores and metal exports as a proportion in total merchandise exports is used to represent the overall natural resource endowment of a host country. Host 
country's technology level (Technology) tests the existence of technology-seeking (or strategic asset-seeking) motivation of Chinese OFDI. It is measured by the share of hightechnology product exports in manufactured exports.

The year dummy $\left(\varphi_{t}\right)$ is included to control for macro-economic effects on all the host countries. The host country dummy $\left(\phi_{i}\right)$ is included to capture all the time-constant unobserved country heterogeneities. $\xi_{i t}$ is an error term.

The definition and data sources of variables discussed above are provided in Appendix A. The data allows us to examine the factors influencing China's OFDI stock in 172 host countries during 2003-09. A list of host countries is reported in Appendix B. The cleaned dataset includes 1,110 observations and accounts for $84 \%$ of China's initial total OFDI stock value. Table 3 reports the summary statistics of all the variables. Figure 2 reveals the relationship between a host country's IFDI stock lagged by one period in China and its contemporaneous OFDI stock in that host country. 
Table 3: Summary statistics 2003-09 (7 years, 172 host countries)

\begin{tabular}{lccccc}
\hline Variable & Obs. & Mean & Standard Difference & Minimum & Maximum \\
\hline lnCOFDIS $_{\text {lnCOFDIS }}$ t-1 & 1110 & 2.716 & 2.550 & -4.605 & 12.011 \\
lnCIFDIS $_{\mathrm{t}-1}$ & 939 & 2.521 & 2.521 & -4.605 & 11.660 \\
lnImportst -1 & 966 & 4.625 & 3.073 & -3.912 & 13.754 \\
lnRGDP & 1134 & 9.679 & 3.561 & -6.908 & 11.924 \\
RGDP_Growth & 1146 & 0.046 & 2.332 & 4.751 & 16.261 \\
lnRGDPPC & 1134 & 7.823 & 0.053 & -0.413 & 0.465 \\
lnExports & 1160 & 6.183 & 1.643 & 4.419 & 11.326 \\
lnOpenness & 1088 & -0.422 & 2.419 & -1.666 & 12.440 \\
Governance & 1195 & 0.499 & 0.731 & -12.482 & 2.777 \\
Inflation & 1061 & 0.311 & 7.502 & 0.104 & 1.025 \\
Resources & 873 & 0.255 & 0.286 & -0.132 & 244.110 \\
Technology & 885 & 0.101 & 0.129 & 0.000 & 0.997 \\
\hline
\end{tabular}

Notes: Obs. $=$ number of observations. Values are measured in current prices in $\$$ million (lnCOFDIS, $\operatorname{lnCOFDIS}_{\mathrm{t}-1}, \operatorname{lnCIFDIS}_{\mathrm{t}-1}$, lnImports $\mathrm{nt}_{\mathrm{t}-1}$, lnExports), in 2000 prices in $\$$ million (lnRGDP, lnRGDPPC), and in percentages (RGDP_Growth, Governance, Inflation, Resources, Technology, lnOpenness). Please see Appendix A for variable definitions.

Figure 2: Relation between China's IFDI and OFDI stocks

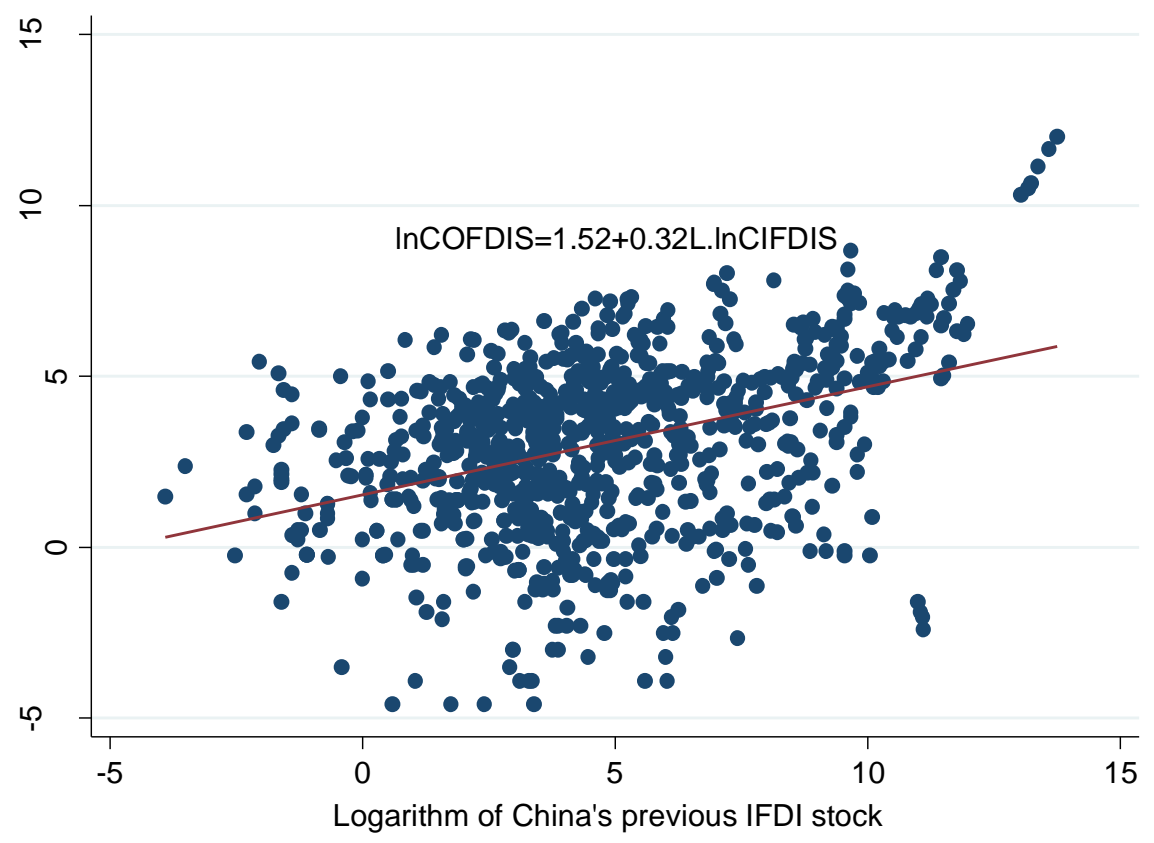

Notes: Logarithms of China's annual IFDI and OFDI were calculated by the authors.

Data sources: MOFCOM (2009) and NBS $(2007,2010)$. 
There are several econometric issues related to the dynamic model of Equation (6). Firstly, the lagged dependent variable is not strictly exogenous as it may be correlated with the disturbance (Greene, 2002). An instrumental variable approach is adopted to avoid this problem. Secondly, the unobserved host country fixed effects, such as geography and demography, may be correlated with the dependent variable. Thirdly, we have a small $\mathrm{N}$ (short time periods $\mathrm{T}=7$ ) and large $\mathrm{N}$ (many host countries $\mathrm{N}=172$ ) panel data. To solve these problems, we use the system GMM developed by Blundell and Bond (1998).

Comparing with the difference GMM estimator (Arellano and Bond 1991), the system GMM obtains a system of two equations, one in levels and one in first differences. More instruments can be obtained and the variables in levels are instrumented with their own first differences (e.g. $\triangle \ln C O F D I S_{i t-1}$ is an instrument for $\left.\ln C O F D I S_{i t-1}\right)$. Therefore, the system GMM is more efficient than the difference GMM. However, the system GMM assumes that the first difference instruments used for the variables in levels are not correlated with the fixed effects (Blundell and Bond, 1998). This assumption depends on the steady state and could be examined by the coefficient of the lagged dependent variable (Roodman 2006). A less than unity value is expected; otherwise the system GMM is not valid. To detect the autocorrelation aside from the fixed effects in levels, we look for the second order correlation $\mathrm{AR}(2)$ in differences. The existence of autocorrelation indicates that the lags of the variables are endogeneous and thus are not proper instruments. To test the joint validity of the instruments set and subsets, we use Hansen J test and difference-in-Hansen test.

Baltagi (2008) argues that system GMM reduces the finite-sample bias and the estimations are consistent and more efficient than other dynamic panel estimations. The system GMM estimation uses a two-step robust regression to correct the finite-sample bias (Windmeijer, 2005). Bond (2002) and Roodman (2006) indicate that ordinary least square (OLS) and fixed 
effects (FE) estimations for a dynamic panel are biased. However, they provide a good check on the validity of GMM estimation by providing the upper and lower bounds, respectively. OLS overestimates the coefficient of the lagged dependent variable because it is positively correlated with errors (Hsiao, 1986) and the FE estimations underestimate the coefficient in a short panel (Nickell, 1981). The validity of system GMM estimation is assured if $\beta_{1}$, the coefficient of lagged dependent variable, lies between the estimations of OLS and FE. Therefore, the results of using OLS and FE estimations are also reported. 


\section{Results and discussions}

\subsection{Baseline Results}

The baseline results are reported in Table 4 for the whole sample. Column (1) presents the OLS regression results without controlling for the country-specific effects. Column (2) presents the FE (fixed effect) regression results by controlling for the country-specific effects. Column (3) presents the system GMM regression results by treating $\operatorname{lnCOFDIS_{t-1}\text {as}}$ endogenous. The coefficient of China's OFDI stock lagged by one period is less than unity, indicating the validity of the system GMM estimation. The value of the estimated coefficient 0.649 lies comfortably below the corresponding upper bound of OLS estimation, 0.790 , and above the corresponding lower bound of FE estimation, 0.326, providing additional evidence of valid estimation.

The validity of system GMM hinges on statistical diagnostics. The F test rejects the null hypothesis and the joint significance is supported. The rejection of the Arellano-Bond AR(1) test and the failure to reject the $\operatorname{AR}(2)$ test indicate that the transformed equation does not serially correlate at the second order, implying that the model is correctly specified. The failure to reject the Hansen test confirms the overall validity of the augmented instruments. The failure to reject the difference-in-Hansen test confirms the validity of the subset instruments.

In column (3), the coefficient of the lagged Chinese OFDI stock is positive and significant at the $1 \%$ level. A $10 \%$ rise in the lagged OFDI stock in a host country is associated with an increase in the current OFDI stock by $6.5 \%$. The result supports the agglomeration effect of OFDI and provides evidence that the positive feedback and self-reinforcement effect of China's past investments drive its current investments in the same direction. This finding is consistent with the result of Cheung and Qian (2009). More importantly, the significance of 
the lagged dependent variable strongly supports the dynamic adjustment of China's OFDI. This will be discussed later.

The results provide evidence that a country's historic FDI stock in China motivates its OFDI stock in that country at the $10 \%$ significance level. A $10 \%$ rise in the lagged IFDI stock from a host country (lnIFDIS $\left.\mathrm{it}_{-1}\right)$ will lead to $1 \%$ increase in the current OFDI stock in that country, ceteris paribus. This finding confirms the positive externality of IFDI stock through information and knowledge spillovers, as well as the commitment to and benefits from business networks.

The results for the other explanatory variables have expected signs and significance. The coefficient on real GDP per capita is negative and significant, indicating that Chinese MNEs care more about the costs of operating business rather than labour productivity. This finding is consistent with the results in Cheng and Ma (2007) and Zhang (2009). Chinese investors prefer the host countries where China exports more goods and services. This finding corroborates a complementary relationship between OFDI and exports. It is also consistent with previous studies on China's OFDI (Buckley et al, 2007; Cheung and Qian, 2009; Zhang, 2009), as well as the argument that China's OFDI is largely distributed in the trade-related sectors. The result of Resources indicates that Chinese OFDI is more likely to be attracted by countries with rich natural resources and confirms the resources-seeking motivation of Chinese OFDI (Buckley et al, 2007; Cheung and Qian, 2009).

The results of real GDP and real GDP growth are not significant, meaning there is no evidence of market-seeking motivations of Chinese MNEs for the whole sample. The insignificant result of technology does not support the technology-seeking or strategic assetseeking motivations of Chinese MNEs. The effects of China's lagged imports from the host 
country and host country's openness, governance, and inflation are not statistically different from zero. 
Table 4: Estimation results for the whole sample

\begin{tabular}{|c|c|c|c|}
\hline & (1) & (2) & (3) \\
\hline $\operatorname{lnCOFDIS}$ & OLS & FE & System GMM \\
\hline \multirow[t]{2}{*}{$\operatorname{lnCOFDIS}_{\mathrm{t}-1}$} & $0.790 * * *$ & $0.326 * * *$ & $0.649 * * *$ \\
\hline & $(0.035)$ & $(0.073)$ & $(0.109)$ \\
\hline \multirow{2}{*}{$\operatorname{lnCIFDIS}_{\mathrm{t}-1}$} & $0.074 * * *$ & -0.024 & $0.098 *$ \\
\hline & $(0.020)$ & $(0.058)$ & $(0.052)$ \\
\hline \multirow[t]{2}{*}{$\operatorname{lnImports}_{\mathrm{t}-1}$} & 0.034 & -0.007 & 0.026 \\
\hline & $(0.029)$ & $(0.065)$ & $(0.035)$ \\
\hline \multirow[t]{2}{*}{$\operatorname{lnRGDP}$} & -0.056 & -0.194 & -0.089 \\
\hline & $(0.063)$ & $(2.074)$ & $(0.108)$ \\
\hline \multirow[t]{2}{*}{ RGDP_Growth } & 0.031 & 0.748 & 0.398 \\
\hline & $(0.880)$ & (1.244) & $(1.112)$ \\
\hline \multirow[t]{2}{*}{$\operatorname{lnRGDPPC}$} & $-0.137 * *$ & -0.917 & $-0.243 * *$ \\
\hline & $(0.055)$ & $(2.134)$ & $(0.106)$ \\
\hline \multirow[t]{2}{*}{$\operatorname{lnExports}$} & $0.164 * * *$ & 0.055 & $0.279 * *$ \\
\hline & $(0.061)$ & $(0.190)$ & $(0.115)$ \\
\hline \multirow[t]{2}{*}{ lnOpenness } & 0.057 & 0.118 & -0.022 \\
\hline & $(0.105)$ & $(0.246)$ & $(0.211)$ \\
\hline \multirow[t]{2}{*}{ Governance } & 0.042 & 2.854 & 0.066 \\
\hline & $(0.340)$ & $(1.880)$ & $(0.531)$ \\
\hline \multirow[t]{2}{*}{ Inflation } & -0.104 & -0.400 & 0.006 \\
\hline & $(0.084)$ & $(0.941)$ & $(0.140)$ \\
\hline \multirow[t]{2}{*}{ Resources } & $0.639 * * *$ & -0.240 & $0.804 * * *$ \\
\hline & $(0.185)$ & $(0.860)$ & $(0.273)$ \\
\hline \multirow[t]{2}{*}{ Technology } & $-0.660 * *$ & 0.301 & -0.202 \\
\hline & $(0.314)$ & $(0.616)$ & $(0.459)$ \\
\hline Country dummy & No & Yes & Yes \\
\hline Year dummy & Yes & Yes & Yes \\
\hline Number of obs. & 554 & 554 & 554 \\
\hline F statistic & 252.80 & 33.51 & 80.31 \\
\hline $\mathrm{AR}(1)$ test & & & 0.001 \\
\hline $\mathrm{AR}(2)$ test & & & 0.508 \\
\hline Hansen $\mathrm{J}$ test & & & 0.570 \\
\hline Difference-in-Hansen & & & 0.385 \\
\hline
\end{tabular}

Notes: *significant at 10\%; ** significant at 5\%; and *** significant at 1\%; robust standard errors in parentheses. $\ln$ COFDIS $_{t-1}$ is endogenous; the levels dated $\mathrm{t}-2$ and earlier are instruments for the transformed equation and the differences dated $\mathrm{t}-1$ are instruments for the level equation. The $\mathrm{F}$ statistic examines the joint significance. The Arellano-Bond $\mathrm{AR}(1)$ and $\mathrm{AR}(2)$ test examines whether the transformed equation is serially correlated at the first order and second order, respectively. The Hansen test examines the over-identification restriction for system GMM estimation. The difference-in-Hansen test examines the validity of instrument subsets in the level equation. $\mathrm{p}$ values are shown for $\operatorname{AR}(1), \operatorname{AR}(2)$, Hansen and difference-in-Hansen tests. Please see Appendix A for variable definitions. 


\subsection{Actual and Equilibrium Stocks of OFDI}

The partial stock adjustment model enables us to restore the unobserved equilibrium stock and to compare it with the actual level. The adjustment process can be written as Equation (7).

$\ln \operatorname{COFDIS}_{i t}^{*}=\frac{1}{\alpha}\left(\ln \operatorname{COFDIS}_{i t}-(1-\alpha) \ln \operatorname{COFDIS}_{i t-1}\right)$

The coefficient on $\operatorname{lnCOFDIS_{it-1}}$ (i.e. $1-\alpha$ ) suggests that the speed of adjustment is $\alpha=1$ $0.649=0.351$. If the above steady state of China's OFDI stock holds, it will take about $1 / \alpha=$ $1 / 0.351 \approx 3$ years to close the gap between the equilibrium and the actual stocks. This gradual adjustment reflects the effect of adjustment cost.

Using Equation (7), we calculate the equilibrium stock of Chinese OFDI. Cheng and Kwan (2000) argue that the changes in equilibrium stock reflect the influences of policy and exogenous variables without the intervention of the adjustment costs and the self-reinforcing effect; and the difference between the actual and equilibrium stocks reflects the potential of the host country in attracting further FDI from China.

To examine the difference between the equilibrium and the actual stocks, we use the same approach in Cheng and Kwan (2000) to calculate the median and median annual growth of the equilibrium OFDI stock and compare them with those of the actual level (Figures 3 and 4). The findings are threefold. Firstly, the equilibrium stock is always bigger than the actual stock in Figure 3, implying that the real OFDI stock was underinvested in general so that Chinese OFDI had huge potential to expand continuously. Secondly, the subprime crisis in 2007 did not have a significant impact on China's OFDI. The median of equilibrium and the median of actual stock remained stable in 2008 and increased in 2009, indicating that China's 
reintegration within the world economy through overseas investments was a long-term strategy and it was not fundamentally altered by a short-term shock.

Figure 3: Medians of equilibrium and actual stock of China's OFDI

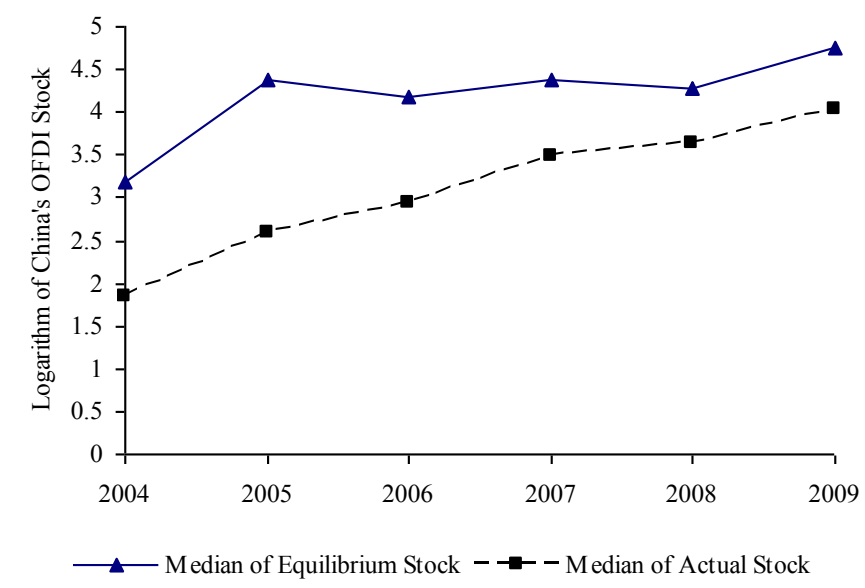

Notes: The median of the equilibrium stock is calculated by the authors.

Data sources: MOFCOM (2009).

Figure 4: Annual growth rates of medians

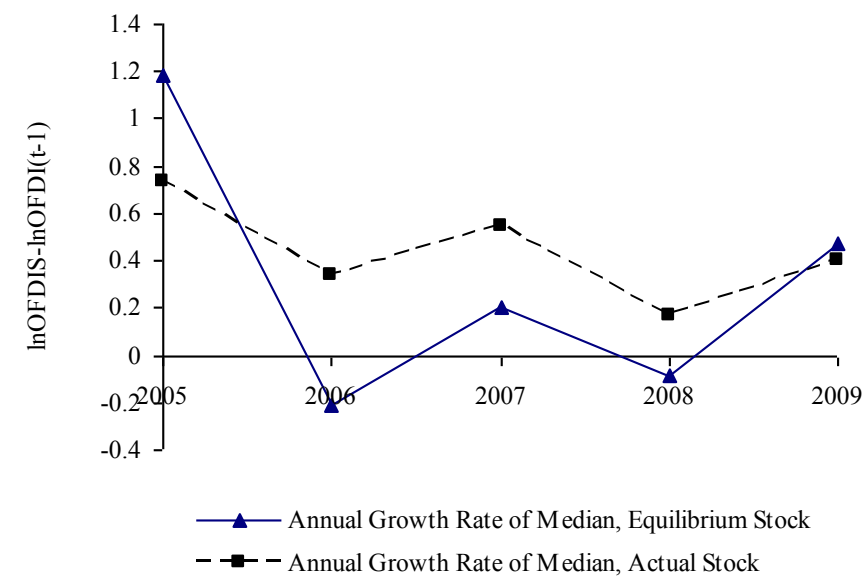

Notes: The annual growth rates of medians are calculated by the authors.

Data source: MOFCOM (2009).

Finally and most importantly, the equilibrium stock was relatively more volatile than the actual level. The subprime crisis had a stronger negative impact on the equilibrium stock than on the actual level. The equilibrium stock is estimated in the absence of the self-reinforcing effect and adjustment cost, thus it responds faster to an exogenous change. Investment inertia 
and adjustment cost slow down the responses of actual stock to exogenous changes. There are various sources for the adjustment cost: the time-to-plan (Christiano and Todd, 1996) and the time-to-build (Casares, 2002). For example, China's overseas investments have to be approved, registered, and supervised by a series of government departments. Such bureaucratic procedure takes time and slows down investment decisions.

To explore the potential of the host country to attract more Chinese capital, we follow Cheng and Kwan (2000) and calculate the dispersion between the actual and the equilibrium stocks, i.e. the logarithm of the ratio of the actual stock over its equilibrium as illustrated by the box plots in Figure 5. The figure shows negative median logarithmic values, indicating that the actual OFDI stock in the host country is underinvested. More importantly, the overtime shrinking dispersions and the stable median implies a trend of relative convergence between the actual and equilibrium stocks. On average, a host country tends to exploit its potential to attract China's investments and the existing investment stock adjusts towards its equilibrium level. This convergence will be more clearly revealed in the following split samples.

Figure 5: Difference between actual and equilibrium OFDI stocks

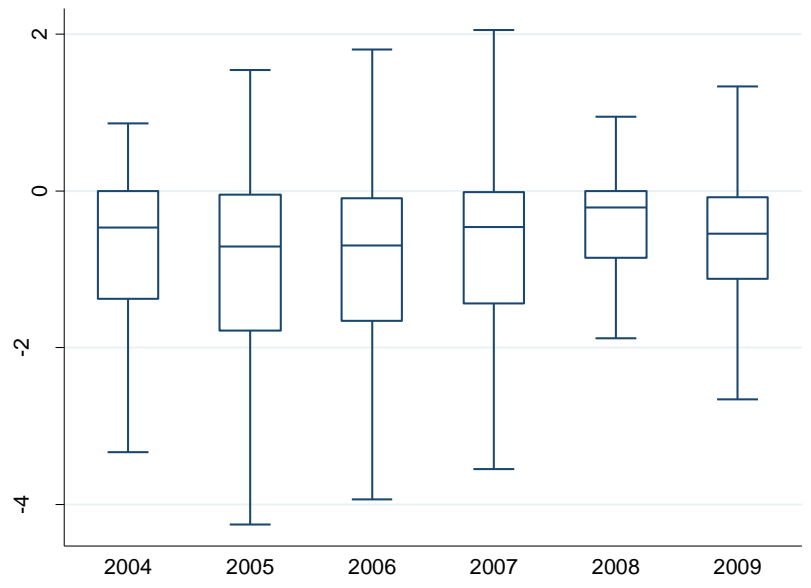

Notes: OFDIS is actual OFDI stock. OFDIS* is the equilibrium stock calculated by the authors. Outside values are excluded.

Data source: MOC (2009). 


\subsection{Results by Host Country's Characteristics}

To examine whether the dynamic adjustment of China's OFDI and the effect of China's IFDI vary with host country's characteristics, we split the whole sample according to their technology level, natural resource endowment and income. ${ }^{1}$ The results using the system GMM estimations are reported in Table 5, which shows that all the specifications pass the tests in all split samples. In particular, the coefficient of lagged China's OFDI stock is less than unity and the steady-state assumption is held. It also lies comfortably below the corresponding upper bound of OLS estimation and above the corresponding lower bound of FE estimation (see Appendix C for the OLS and FE results).

Table 5: System GMM results by host country's characteristics

\begin{tabular}{|c|c|c|c|c|c|c|}
\hline \multirow[b]{3}{*}{$\operatorname{lnCOFDIS}$} & \multicolumn{2}{|c|}{ Technology } & \multicolumn{2}{|c|}{ Natural resources } & \multicolumn{2}{|c|}{ Income level } \\
\hline & (1) & (2) & (3) & $\begin{array}{l}(4) \\
\text { Less }\end{array}$ & (5) & (6) \\
\hline & High & Low & Abundant & Abundant & High & Low \\
\hline $\begin{array}{l}\operatorname{lnCOFDIS}_{\mathrm{t}-1} \\
(1-\alpha)\end{array}$ & $\begin{array}{c}0.628 * * * \\
(0.133)\end{array}$ & $\begin{array}{c}0.385 * * \\
(0.163)\end{array}$ & $\begin{array}{c}0.470 * * * \\
(0.126)\end{array}$ & $\begin{array}{c}0.524 * * * \\
(0.130)\end{array}$ & $\begin{array}{c}0.614 * * * \\
(0.137)\end{array}$ & $\begin{array}{c}0.657 * * * \\
(0.138)\end{array}$ \\
\hline $\operatorname{lnCIFDIS}_{\mathrm{t}-1}$ & $\begin{array}{c}0.158 * * \\
(0.074) \\
\end{array}$ & $\begin{array}{l}0.140 * \\
(0.077) \\
\end{array}$ & $\begin{array}{c}0.026 \\
(0.050) \\
\end{array}$ & $\begin{array}{c}0.159 \\
(0.102) \\
\end{array}$ & $\begin{array}{c}0.177 * * * \\
(0.064)\end{array}$ & $\begin{array}{c}0.017 \\
(0.026) \\
\end{array}$ \\
\hline Country dummy & Yes & Yes & Yes & Yes & Yes & Yes \\
\hline Year dummy & Yes & Yes & Yes & Yes & Yes & Yes \\
\hline Control variables & Yes & Yes & Yes & Yes & Yes & Yes \\
\hline $\begin{array}{l}\text { Speed of adjustment } \alpha \\
\text { Year of adjustment }\end{array}$ & 0.372 & 0.615 & 0.530 & 0.476 & 0.386 & 0.343 \\
\hline $1 / \alpha$ & 3 & 2 & 2 & 2 & 3 & 3 \\
\hline Number of obs. & 302 & 252 & 280 & 274 & 347 & 207 \\
\hline F statistic & 48.27 & 23.73 & 28.29 & 27.24 & 51.25 & 76.69 \\
\hline $\mathrm{AR}(1)$ test & 0.014 & 0.060 & 0.027 & 0.015 & 0.005 & 0.006 \\
\hline $\mathrm{AR}(2)$ test & 0.750 & 0.259 & 0.577 & 0.624 & 0.666 & 0.938 \\
\hline Hansen $\mathrm{J}$ test & 0.515 & 0.780 & 0.159 & 0.218 & 0.545 & 0.264 \\
\hline Difference-in-Hansen & 0.439 & 0.605 & 0.224 & 0.154 & 0.395 & 0.328 \\
\hline
\end{tabular}

Notes: *significant at 10\%; ** significant at 5\%; and *** significant at 1\%; robust standard errors in parentheses. $\ln C O F D I S_{t-1}$ is endogenous; the levels dated $\mathrm{t}-2$ and earlier are instruments for the transformed equation and the differences dated $\mathrm{t}-1$ are instruments for the level equation. The F statistic examines the joint significance. The Arellano-Bond AR(1) and AR(2) test examines whether the transformed equation is serially correlated at the first order and second order, respectively. The Hansen test examines the over-identification restriction for system GMM estimation. The difference-in-Hansen test examines the validity of instrument subsets in the level equation. $\mathrm{p}$ values are shown for AR(1), AR(2), Hansen and difference-in-Hansen tests. The results of other variables are available upon request. Please see Appendix A for variable definitions.

\footnotetext{
${ }^{1}$ A host country is classified as a high-technology country if the value of Technology variable exceeds the median value; otherwise, it is a low-technology country. A country is defined as natural resource abundant if its value of Resource variable exceeds the median value, or vice versa. Similarly, A country is high income if its real GDP per capita exceeds the median value, and vice versa.
} 
The results for high- and low-technology host countries are presented in columns (1) and (2) in Table 5, respectively. The coefficients on China's OFDI stock lagged by one period are positive and significant at the $5 \%$ level or below. The agglomeration effect of lagged OFDI is strong in both subsamples but is bigger in the high-tech host countries. The speed of adjustment is lower in high-tech countries (0.372) than that in low-tech ones (0.615), indicating a higher adjustment cost in the former than in the latter. For example, the set-up cost in high-tech countries may be higher for Chinese MNEs in conducting a new investment such as employing skilled labour and experts. If the steady state of China's OFDI stock holds, it will take about 3 and 2 years to close the gap between the equilibrium and actual stocks in the two split samples, respectively.

Figure 6 presents the medians of the equilibrium and actual stocks of China's OFDI for both the high- and low-tech host countries. The equilibrium stock is greater in the high-tech countries than in the low-tech ones. One possible explanation is that technology-seeking motivation tends to drive China's OFDI to high-tech host countries but it requires time to do so. Wang and Blomstrom (1992) explicitly point out that, although technology spillovers are intrinsic, they do not take effect automatically. The more learning investments are conducted by a technologically inferior company in absorbing advanced technology, the higher is the transfer rate of technology spillovers to active investors. Therefore, China's final OFDI stock in high-tech host countries might be higher. We also find the equilibrium stock is more volatile than the actual stock in both split samples. Interestingly, the difference between the equilibrium and actual stocks in the high-tech countries is generally greater than that in the low-tech ones, which is consistent with the slower adjustment speed and higher adjustment cost of Chinese OFDI in the former than in the latter. 
Figure 6: Median of equilibrium/actual OFDI stocks in high-/low-tech countries

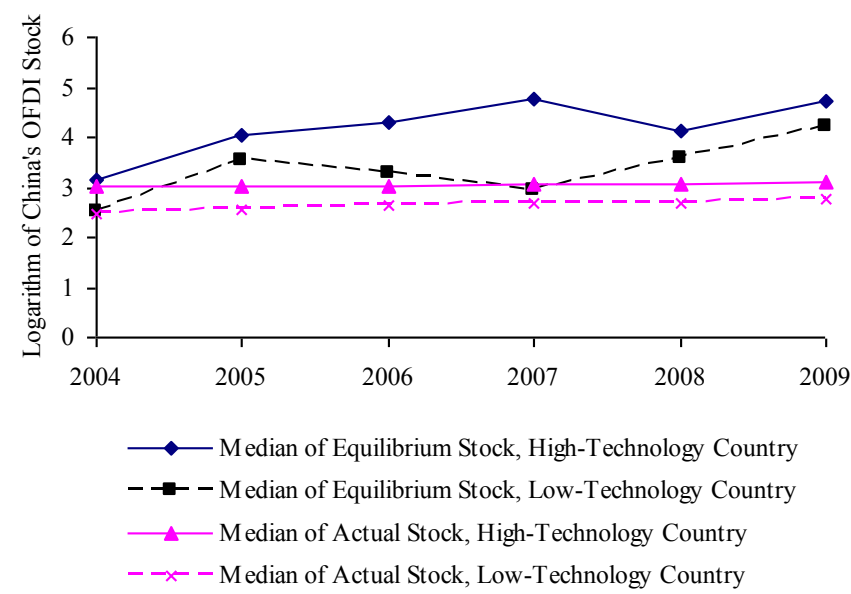

Notes: The median of the equilibrium stock is calculated by the authors.

Data source: MOFCOM (2009).

Figure 7 shows the deviations of China's actual OFDI stock from its equilibrium levels in both subsamples. The negative medians imply that China's OFDI is underinvested in the two subsamples. The smaller median in high-tech countries implies that China's investments there have greater potential than in the low-tech economies.

Figure 7: Differences between actual and equilibrium stocks in high- and low-technology countries

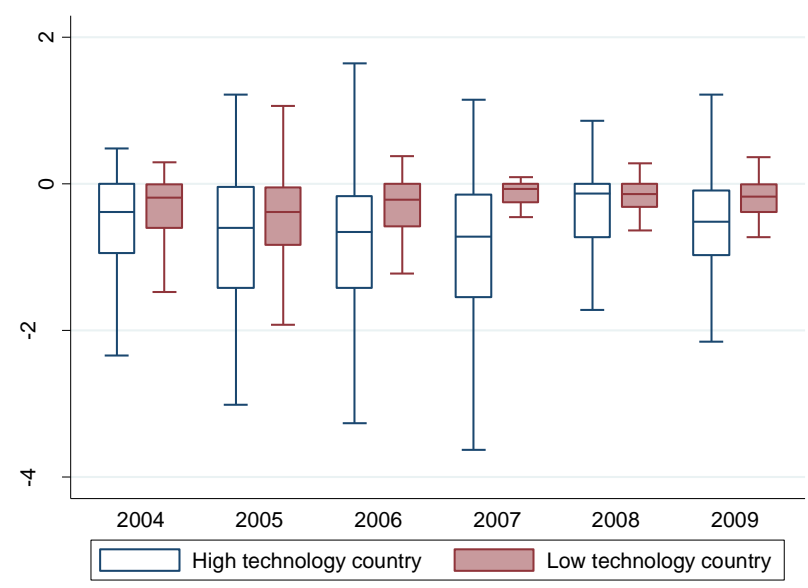

Notes: OFDIS is China's actual OFDI stock. OFDIS* is the equilibrium stock calculated by the authors. Outside values are excluded.

Data source: MOFCOM (2009).

Furthermore, we also find the overtime shrinking dispersion of the difference between China's actual and equilibrium OFDI stocks plus a stable median in both split samples in

Figure 7. The dispersion for the high-tech countries was greater than for the low-tech ones, 
which is in line with the above findings of slow adjustment speed of actual stock towards its equilibrium level in the former than in the latter.

Columns (3) and (4) in Table 5 are the results for natural resource abundant and less abundant countries, respectively. Columns (5) and (6) respectively report the results for high and low income countries. The coefficients on the lagged Chinese OFDI stock in all columns are significant and positive. The speed of adjustment or the number of years to close the gap between the equilibrium and the actual stocks are similar between columns (3) and (4), as well as between columns (5) and (6).

Figures 8-9 show the medians of, and the dispersion between, the actual and the equilibrium stocks in the resource rich and poor countries, Figures 10-11 show the corresponding values in the high- and low-income countries.

Figure 8: Medians of China's equilibrium and actual OFDI stocks in resources abundant and less abundant countries

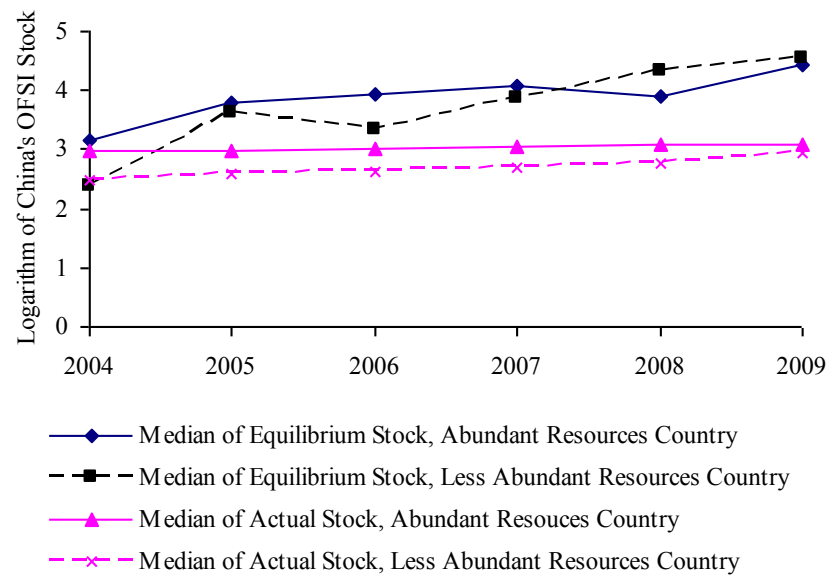

Notes: The median of the equilibrium stock is calculated by the authors. Data source: MOFCOM (2009). 
Figure 9: Differences between actual and equilibrium stocks in resources abundant and less abundant countries

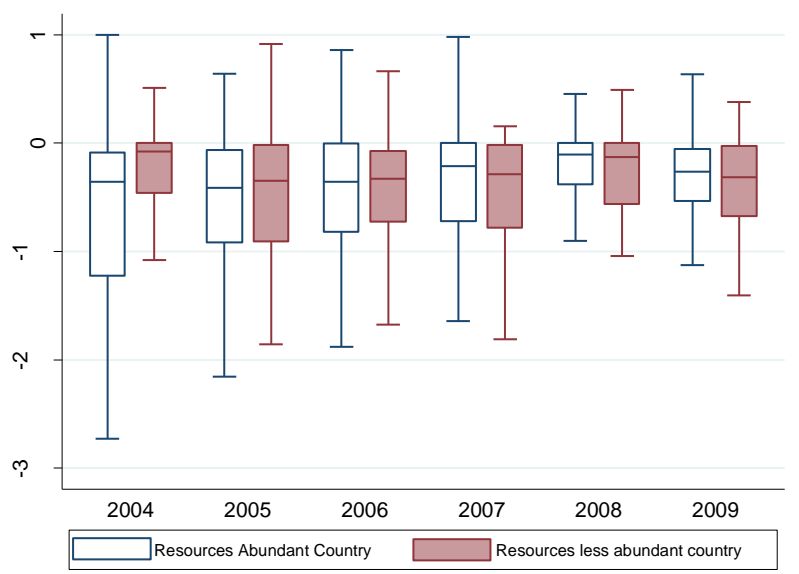

Notes: OFDIS is China's actual OFDI stock. OFDIS* is the equilibrium stock calculated by the authors. Outside values are excluded.

Data source: MOFCOM (2009).

Figure 10: Medians of China's equilibrium and actual OFDI stocks in high-and low-income countries

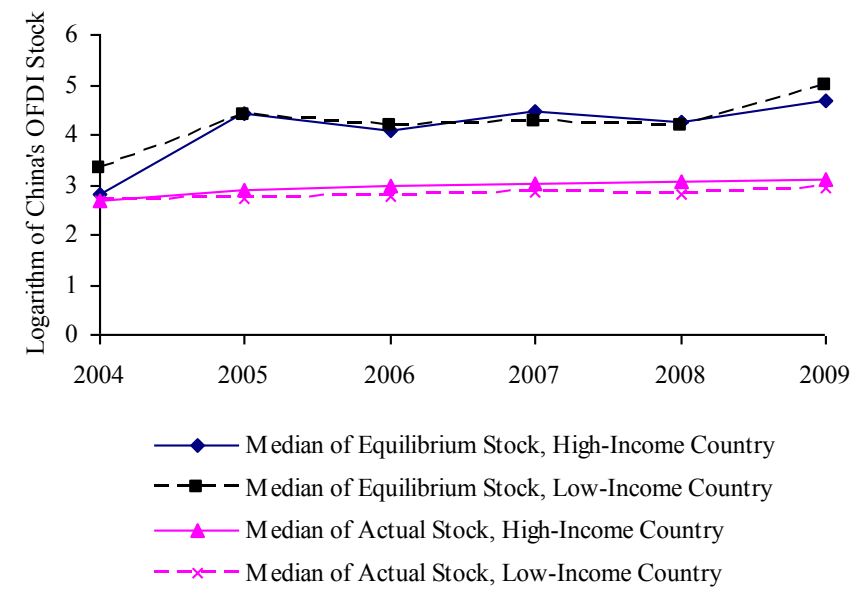

Notes: The median of the equilibrium stock is calculated by the authors.

Data source: MOFCOM (2009)

Figure 11: Differences between actual and equilibrium stocks in high- and low-income countries 


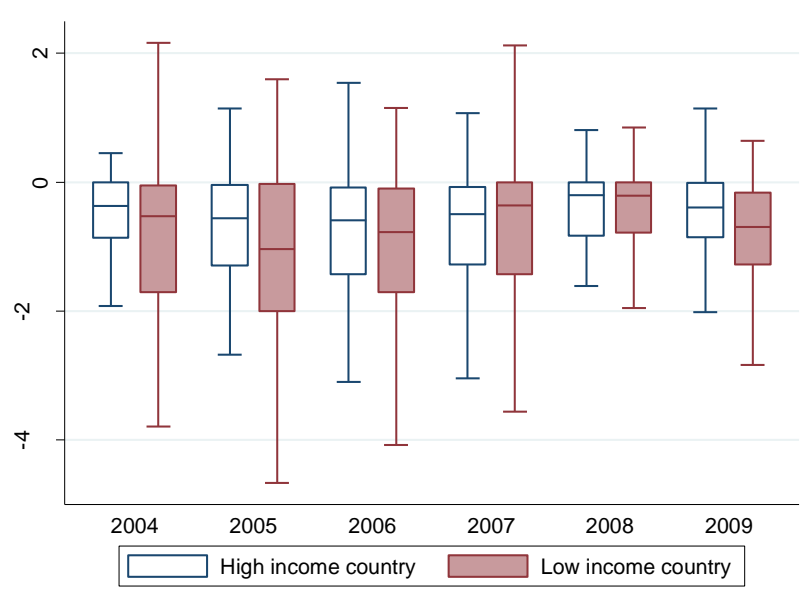

Notes: OFDIS is China's actual OFDI stock. OFDIS* is the equilibrium stock calculated by the authors. Outside values are excluded.

Data source: MOC (2009).

The results are consistent with those in the previous sections. The equilibrium stock was always more volatile than the actual level in all split samples. The difference between the equilibrium and actual stocks in resources rich countries was similar to that in resource poor ones, so is that between the high- and low-income countries.

These findings confirm the similar adjustment speeds (or adjustment costs) in both groups. China's OFDI was underinvested in all subsamples so host countries have potential to attract more Chinese FDI, irrespective of their resource endowment or level of economic development. There is a relative convergence in terms of actual stock to its equilibrium level in all subsamples, and similar dispersions.

Finally, the lagged IFDI stock has a positive and significant effect on contemporaneous Chinese OFDI stock in both high- and low-tech countries, while its impact is not statistically different from zero in countries with either abundant or less abundant resources. Given the spillover effects of IFDI are largely generated in manufacturing industries, the spilled information about host country technology is relevant to China's future investment in these countries while the spilled information about host country natural resources might not be 
relevant. We also find that the more previous investment in China from high income countries the more Chinese investment will flow back there, while such an effect is not significant for low income countries. One possible explanation is that consumer demand in high-income countries is more diversified, and the spilled information might include consumer preferences. For example, the US is one of top IFDI source countries in China. The accumulated investments from the US might provide an opportunity for China to better understand consumer preferences in the American market, and hence promote subsequent Chinese investments. The investment of Haier in the US to design and produce fridges and to quickly become a leading brand is a successful case in point. Overall, we find some evidence to support the positive association between China's IFDI and OFDI across all specifications.

\subsection{Robustness Checks}

We also undertake a range of robustness checks to examine the sensitivity of the findings. We used the levels dated t-2 and earlier as instruments for the transformed equation in the system GMM estimations, the results do not alter the signs and significance of the main variables of interest. The magnitudes of the estimated coefficients are also similar. To further correct the skewness to tax havens and offshore financial centres that may affect the actual volume of China's OFDI stock, we drop Hong Kong and Macao from the sample. Thus the roundtripping investment (Wong and Chan, 2003; Xiao, 2004) to these two SARs is excluded. The results are robust across all specifications. We also drop 4 observations with extremely high governance indexes, but the results are similar to the main results reported in the text. 


\section{Conclusions}

This paper examines the dynamic adjustment of China's OFDI and its relation to IFDI, using a panel dataset for China's OFDI stock in 172 host countries during 2003-09. To our best knowledge, this is the first study using a partial stock adjustment model to study China's overseas investment behaviour in a dynamic framework. The partial stock adjustment model enables us to restore the unobservable equilibrium OFDI stock value. The comparison between the actual and the equilibrium stocks sheds light on the potential of China's OFDI from a new dimension. In addition, this paper reveals the link between China's IFDI and OFDI, which has yet to be examined systematically in existing studies. It further investigates whether and how the dynamic adjustment of China's OFDI and the effect of China's IFDI vary with host country characteristics including technology, resources and income.

The findings reveal strong evidence for the dynamic adjustment of China's OFDI and the agglomeration and self-reinforcement effect. The significance of dynamic adjustment reveals the existence of a substantial adjustment cost in China's OFDI and implies that the existing stock gradually adjusts towards its equilibrium level. The results indicate that the restored equilibrium is not only bigger but also more volatile than the actual stock. The findings also suggest that the host country, on average, exploits its potential to attract China's future investments. There is some evidence for the positive association between China's lagged IFDI and its contemporaneous OFDI. In addition, the dynamic adjustment of China's OFDI and the agglomeration effect are both stronger in high-technology countries than in lowtechnology ones. In contrast, they do not vary with the host country's natural resources and income levels. There is some evidence of a positive relation for high-income countries, but not for low-income ones, and the correlation is not conditional on the host country technology level. 
The present study has two implications. Firstly, the existence of adjustment cost constrains the potential of China's OFDI, and a further liberalisation of the approval regime would be helpful in reducing the adjustment cost. Secondly, the Chinese government should provide more information about host countries, as this valuable information would help Chinese MNEs to better understand the foreign market and to respond faster to future investment opportunities. As for host countries, it implies that it is imperative to understand the Chinese political and economic system better if you wish to attract more Chinese capital.

The dataset used in this study has two limitations. Firstly, the aggregate measure of IFDI stock cannot reflect the mechanisms through which the externality effect takes place or explain the difference between sectors. Secondly, the OFDI stock data was collected from Ministry of Commerce (MOFCOM) that only reported OFDI stock in non-financial sectors over the period 2003-2006; therefore, it might lead to the underestimation of equilibrium stocks of OFDI. 


\section{References}

Apergis, N. (2009). Foreign Direct Investment, Inward and Outward; Evidence from Panel Data, Developed and Developing Economies, and Open and Close Economies. American Economist, 54(2): 21-27.

Arellano, M. and Bond, S., 1991. Some Tests of Specification for Panel Data: Monte Carlo Evidence and an Application to Employment Equations. Review of Economic Studies, 58, 277-297.

Baltagi, B. H., 2008. Econometric Analysis of Panel Data. $4^{\text {th }}$ edition. Chichester: John Wiley \& Sons Ltd.

Barrell, R. and Pain, N., 1999. Domestic Institutions, Agglomerations and Foreign Direct Investment in Europe. European Economic Review, 43, 925-934.

Blonigen, B. A., 2001. In Search of Substitution between Foreign Production and Exports. Journal of International Economics, 53(1), 81-104.

Blonigen, B. A., 2005. A Review of the Empirical Literature on FDI Determinants. NBER Working Paper 11299.

Blundell, R. and Bond, S., 1998. Initial Conditions and Moment Restrictions in Dynamic Panel Data Models. Journal of Econometrics, 87(1), 115-143.

Bond, S., 2002. Dynamic Panel Data Models: A Guide to Micro Data Methods and Practice. Working Paper 09/02. Institute for Fiscal Studies. London.

Brainard, S. L., 1997. An Empirical Assessment of the Proximity-Concentration Tradeoff between Multinational Sales and Trade. American Economic Review, 87(4), 520-544.

Buckley, P. J. and Casson, M., 1976. The Future of the Multinational Enterprise. London: Macmillan.

Buckley, P., Clegg, J., and Wang, C. 2002. The impact of inward FDI on the performance of Chinese manufacturing firms. Journal of International Business Studies 38: 447-459.

Buckley, P. J., Clegg, L. J., Cross, A. R., Liu, X., Voss, H. and Zheng, P., 2007. The Determinants of Chinese Outward Foreign Direct Investment. Journal of International Business Studies, 38, 499-518.

Campos, N. F. and Kinoshita, Y., 2003. Why Does FDI Go Where It Goes? New evidence from the Transition Economies. IMF Working Paper 03/228.

Casares, M., 2002. Time-to-build Approach in A Sticky Price; Sticky Wage Optimizing Monetary Model. Working Paper Series 147, European Central Bank.

Cheng, L. K. and Kwan, Y. K., 2000. What Are the Determinants of the Location of Foreign Direct Investment? The Chinese Experience. Journal of International Economics, 51, 379-400. 
Cheng, L. K., \& Ma, Z., 2007. China's Outward FDI: Past and Future. School of Economics, Renmin University, Working Paper no. 2007706001E, Beijing.

Cheung, Y. W. and Qian, X. W., 2009. The Empirics of China's Outward Direct Investment. Pacific Economic Review, 14(3), 312-341.

Child, J., and Rodrigues, S., 2005. The Internationalization of Chinese Firms: A Case for Theoretical Extension? Management and Organization Review, 1(3), 381-410.

Chow, G. C., 1967. Technological Change and the Demand for Computers. American Economic Review, 57(5): 1117-1130.

Christiano, L. J. and Todd, R. M., 1996. Time to Plan and Aggregate Fluctuations. Federal Reserve Bank of Mineapolis Quarterly Review, 20(1), 14-27.

Cole, M.A., Elliott, R.J.R., and Zhang, J., 2009. Corruption, Governance and FDI Location in China: A Province-Level Analysis. Journal of Development Studies, 45(9), 1494-1512.

Dees, S. (1998). Foreign direct investment in China: determinants and effects. Economics of Planning, 31(2-3), 175-194. http://dx.doi.org/10.1023/A:1003576930461.

Driffield, N. and Love, J. H., 2003. Foreign Direct Investment, Technology Sourcing and Reverse Spillovers. The Manchester School, 71, 659-672.

Dunning, J. H., Kim, C. and Lin, J., 2001. Incorporating Trade Ratio into the Investment Development Path: A Case Study of Korea and Taiwan. Oxford Development Studies, 29(2), 145-154.

$\mathrm{Fu}, \mathrm{X}$. and Gong, Y. 2011. Indigenous and foreign innovation efforts and technological upgrading in emerging economies: firm-level evidence from China. World Development 39 , no. 7:1213-1225.

Globerman, S. and Shapiro, D., 2002. Global Foreign Direct Investment Flow: The Role of Governance Infrastructure. World Development, 30(11), 1899-1919.

Greene, W. H., 2002. Econometric Analysis (5th ed.). New York: Prentice-Hall.

Grubert, H. and Mutti, J., 1991. Taxes, Tariffs and Transfer Pricing in Multinational Corporate Decision Making. The Review of Economics and Statistics, 78, 285-293.

Habib, M. and Zurawicki, L., 2002. Corruption and Foreign Direct Investment. Journal of International Business Studies, 33(2), 291-307.

Hanson, G. H., Mataloni, R. J. and Slaughter, M. J., 2001. Expansion Strategies of U.S. Multinational Firms. NBER Working Paper 8433.

Head, K. and Ries, J., 2001. Overseas Investment and Firm Exports. Review of International Economics, 9(1), 108-122. 
Helpman, E., 1984. A Simple Theory of Trade with Multinational Corporations. Journal of Political Economy, 92, 451-571.

Hertenstein, P., Sutherland, D., and Anderson, J., 2015. Internationalization within Networks: Exploring the Relationship between Inward and Outward FDI in China's Auto Components Industry. Asia Pacific Journal of Management, online first, DOI: 10.1007/s10490-015-9422-3.

Hsiao, C., 1986. Analysis of Panel Data. Cambridge: Cambridge University Press.

Hu, A.G.Z. and Jefferson, G. H. 2002. FDI impact and spillover: evidence from China's electronic and textile industries. The World Economy 25, no. 8: 1063-1076.

Katherin, M. and Cornelia, M. C., 2007. Is China on the Investment Development Path? Journal of Asia Business Studies, 1(2), 1-9.

Kolstad I. and Wiig, A., 2012. What Determines Chinese Outward FDI? Journal of World Business, 47 (1): 26-34

Li, J., Li, Y., and Shapiro, D., 2012. Knowledge Seeking and Outward FDI of Emerging Market Firms: The Moderating Effect of Inward FDI. Global Strategy Journal, 2 (4):277295.

Liu, X. H., Buck, T. and Shu, C., 2005. Chinese Economic Development, the Next Stage: Outward FDI? International Business Review, 14, 97-115.

Luo, Y. and Tung, R. L., 2007. International Expansion of Emerging Market Enterprises: A Springboard Perspective. Journal of International Business, 38 (4):481-498.

Luo, Y., Xue, Q., and Han B., 2010. "How Emerging Market Governments Promote Outward FDI: Experience from China. Journal of World Business, 45 (1), 68-70

Makino, S., Lau, C. M., \& Yeh, R. S., 2002. Asset-Exploitation Versus Asset-Seeking: Implications for Location Choice of Foreign Direct Investment from Newly Industrialized Economies. Journal of International Business Studies, 33(3): 403-421.

Markusen, J. R., 1984. Multinationals, Multi-Plant Economies, and the Gains from Trade. Journal of International Economics, (16), 205-226.

Ministry of Commerce People's Republic of China (MOFCOM), 2009. Statistical Bulletin of China's Outward Foreign Direct Investment. Available at http://images.mofcom.gov.cn/hzs/accessory/201009/1284339524515.pdf, (Accessed 6 September 2013).

Mo, Z. (2014). Inward Foreign Direct Investment, Entrepreneurial Behavior, and Outward Foreign Direct Investment: Evidence from China. International Journal of Business and Management, 9(9): 108-117.

Morck, R., Yeung, B., \& Zhao, M. 2008. Perspectives on China's Outward Foreign Direct Investment. Journal of International Business Studies, 39, 13. 
National Bureau of Statistics (NBS), 2007, 2010. China Trade and External Economic Statistical Yearbook. China Statistical Press, Beijing.

Nickell, S., 1981. Biases in Dynamic Models with Fixed Effects. Econometrica, 49(6), 14171426.

Ning, L., and Sutherland, D., 2012. Internationalization of China's Private-Sector MNEs: An Analysis of the Motivations for Foreign Affiliate Formation. Thunderbird International Business Review, 54(2):169-182.

Oulton, N., 1996. Increasing Returns and Externalities in UK Manufacturing: Myth or Reality? Journal of Industrial Economics, 44, 99-113.

Ramasamy, B., Yeung, M. and Laforet, S., 2012. China's Outward Foreign Direct Investment: Location Choice and Firm Ownership. Journal of World Business, 47 (1): 17-25

Roodman, D., 2006. How to Do xtabond2: An Introduction to "Difference" and "System" GMM in Stata. Center for Global Development Working Paper 103.

Sauvant, K. P., 2011. China: Inward and Outward Foreign Direct Investment. Transnational Corporations Review, 3(1), i-iii.

Sauvant, K. P., Jost, T., Davies, K. and Garcés, A. M. P., 2011. Inward and Outward FDI Country Profiles, New York: Vale Columbia Center on Sustainable International Investment.

United Nations Conference on Trade and Development (UNCTAD), 2007. Rising FDI into China: The Facts behind the Numbers, UNCTAD Investment Brief No. 2-2007.

UNCTAD, 2013. World Investment Report 2013, Global Value Chains: Investment and Trade for Development. New York and Geneva: United Nations.

Wagner, W. J. and Timmins, C. D., 2009. Agglomeration Effects in Foreign Direct Investment and the Pollution Haven Hypothesis. Environ Resource Econ, 43, 231-256.

Wang, J. Y. and Blomstrom, M., 1992. Foreign Investment and Technology Transfer, A Simple Model. European Economic Review, 36(1), 137-155.

Wei, S. (1995). The open door policy and China's rapid growth: evidence from city-level data. In T. Ito \& A. Krueger (Eds.), Growth Theories in Light of the East Asian Experience. London and Chicago: The University of Chicago Press.

Wheeler, D. and Mody, A., 1992. International Investment Location Decisions: The Case of U.S. Firms. Journal of International Economics, 33, 57-76.

Windmeijer, F., 2005. A Finite Sample Correction for The Variance of Liner Efficient TwoStep GMM Estimators. Journal of Econometrics, 126, 25-51.

Wong, J. and Chan, S., 2003. China's Outward Direct Investment: Expanding Worldwide. China: An International Journal, 1(2), 273-301. 
Woo, W. T. (1995). Comments on Wei's paper (1995) Foreign direct investment in China: source and consequences. In A. Krueger (Ed.), Financial Deregulation and Integration in East Asia (pp. 166-189). The University of Chicago Press, Chicago.

World Bank, 2010. The Worldwide Governance Indicators. World Bank, Washington, DC.

Xiao, G., 2004. People's Republic of China's Round-Tripping FDI: Scale, Causes and Implications. University of Hong Kong, Working Paper.

Xiao, J. and Sun, F., 2005. The Challenges Facing Outbound Chinese M\&A. International Financial Law Review, 24(12), 44-46.

Yamakawa, Y., Peng, M. W., \& Deeds, D. L., 2008. What Drives New Ventures to Internationalize from Emerging to Developed Economies? Entrepreneurship: Theory and Practice, 32(1): 59-82.

Yao, S. and Sutherland, D., 2009. Chinalco and Rio Tinto: A Long March for China's National Champions. China Quarterly, September, 199, 829-36.

Yao, S. J., Sutherland, D. and Chen, J., 2010. China's Outward FDI and Resouce-Seeking Strategy: A Case Study on Chinalco and Rio Tinto. Asia-Pacific Journal of Accounting \& Economics, 17, 313-326.

Yao, S., and Wang, P., 2014. Has China Displaced The Outward Investments of OECD Countries? China Economic Review, 29(C), 55-71.

Yeaple, S. R., 2003. The Role of Skill Endowments in the Structure of U.S. Outward Foreign Direct Investment. Review of Economics and Statistics, 85(3), 726-734.

Zhang, X. and Daly, K., 2011. The Determinants of China's Outward Foreign Direct Investment. Emerging Markets Review, 12(4):389 - 398

Zhang, Y., 2009. Unravelling the Complex Motivation behind China's FDI. Tjalling C. Koopmans research Institute, Discussion Paper Series 09-02. 


\begin{tabular}{|c|c|c|}
\hline Variables & Description & Data Sources \\
\hline $\ln C O F D I S$ & $\begin{array}{l}\text { value of China's OFDI stock, in } \\
\$ \text { million and logarithm }\end{array}$ & $\begin{array}{l}\text { Ministry of Commerce of China, } \\
2009 \text { Statistical Bulletin of } \\
\text { China's OFDI }\end{array}$ \\
\hline $\ln C O F D I S_{t-1}$ & $\begin{array}{l}\text { The above variable lagged by one } \\
\text { year }\end{array}$ & as above \\
\hline $\ln C I F D I S_{t-1}$ & $\begin{array}{l}\text { China's IFDI lagged by one year } \\
\text { in } \$ \text { million and logarithm }\end{array}$ & $\begin{array}{l}\text { National Bureau of Statistics } \\
(2007,2010) \text { China Trade and } \\
\text { External Economic Statistical } \\
\text { Yearbook }\end{array}$ \\
\hline lnImports $_{t-1}$ & $\begin{array}{l}\text { China's imports of goods and } \\
\text { services from a host country in } \\
\text { current US million dollars and } \\
\text { logarithm }\end{array}$ & IMF, Direction of Trade \\
\hline $\ln R G D P$ & $\begin{array}{l}\text { real GDP at constant } 2000 \text { price, } \\
\$ \text { million in logarithm }\end{array}$ & $\begin{array}{l}\text { World Bank, World Development } \\
\text { Indicators }\end{array}$ \\
\hline RGDP_Growth & annual growth rate of real GDP & as above \\
\hline $\ln R G D P P C$ & real GDP per capita in logarithm & as above \\
\hline lnExports & $\begin{array}{l}\text { China's exports of goods and } \\
\text { services to a host country in } \\
\text { current US million dollars and } \\
\text { logarithm }\end{array}$ & IMF, Direction of Trade \\
\hline InOpenness & Trade/GDP, in logarithm & $\begin{array}{ll}\text { World } \quad \text { Bank, } & \text { World } \\
\text { Development Indicators } & \end{array}$ \\
\hline Governance & $\begin{array}{l}\text { control of corruption and a higher } \\
\text { value indicates a low degree of } \\
\text { corruption }\end{array}$ & $\begin{array}{l}\text { World Bank } \\
\begin{array}{l}\text { Worldwide } \\
\text { Indicators }\end{array}\end{array}$ \\
\hline Inflation & ratio of annual inflation rate & $\begin{array}{l}\text { World Bank, World Development } \\
\text { Indicators }\end{array}$ \\
\hline Resources & $\begin{array}{l}\text { share of fuels, ores \& metals } \\
\text { exports in merchandise exports }\end{array}$ & as above \\
\hline Technology & $\begin{array}{l}\text { share of high-technology exports } \\
\text { in manufactured exports }\end{array}$ & as above \\
\hline
\end{tabular}




\begin{tabular}{|c|c|c|c|c|c|c|c|}
\hline 1 & Afghanistan & 44 & Djibouti & 87 & Liberia & 130 & Rwanda \\
\hline 2 & Albania & 45 & Dominica & 88 & Libyan & 131 & $\begin{array}{l}\text { Saint Vincent \& } \\
\text { Grenadines }\end{array}$ \\
\hline 3 & Algeria & 46 & East Timor & 89 & Liechtenstein & 132 & Samoa \\
\hline 4 & Angola & 47 & Ecuador & 90 & Lithuania & 133 & Saudi Arabia \\
\hline 5 & $\begin{array}{l}\text { Antigua and } \\
\text { Barbuda }\end{array}$ & 48 & Egypt & 91 & Luxembourg & 134 & Senegal \\
\hline 6 & Argentina & 49 & $\begin{array}{l}\text { Equator } \\
\text { Guinea }\end{array}$ & 92 & Macau & 135 & Serbia \\
\hline 7 & Armenia & 50 & Eritrea & 93 & Macedonia & 136 & Seychelles \\
\hline 8 & Australia & 51 & Estonia & 94 & Madagascar & 137 & Sierra Leone \\
\hline 9 & Austria & 52 & Ethiopia & 95 & Malawi & 138 & Singapore \\
\hline 10 & Azerbaijan & 53 & Fiji & 96 & Malaysia & 139 & Slovakia \\
\hline 11 & Bahamas & 54 & Finland & 97 & Mali & 140 & Slovenia \\
\hline 12 & Bahrain & 55 & France & 98 & Malta & 141 & South Africa \\
\hline 13 & Bangladesh & 56 & Gabon & 99 & Marshall & 142 & South Korea \\
\hline 14 & Barbados & 57 & Gambia & 100 & Mauritania & 143 & Spain \\
\hline 15 & Belarus & 58 & Georgia & 101 & Mauritius & 144 & Sri Lanka \\
\hline 16 & Belgium & 59 & Germany & 102 & Mexico & 145 & Sudan \\
\hline 17 & Belize & 60 & Ghana & 103 & Micronesia & 146 & Suriname \\
\hline 18 & Benin & 61 & Greece & 104 & Moldova & 147 & Sweden \\
\hline 19 & Bermuda & 62 & Grenada & 105 & Mongolia & 148 & Switzerland \\
\hline 20 & Bolivia & 63 & Guinea & 106 & Montenegro & 149 & Syrian Arab Rep \\
\hline 21 & $\begin{array}{l}\text { Bosnia and } \\
\text { Herzegovina }\end{array}$ & 64 & Guyana & 107 & Morocco & 150 & Taiwan \\
\hline 22 & Botswana & 65 & Honduras & 108 & Mozambique & 151 & Tajikistan \\
\hline 23 & Brazil & 66 & Hong Kong & 109 & Myanmar & 152 & Tanzania \\
\hline 24 & Brunei & 67 & Hungary & 110 & Namibia & 153 & Thailand \\
\hline 25 & Bulgaria & 68 & Iceland & 111 & Nepal & 154 & Togo \\
\hline 26 & Burundi & 69 & India & 112 & Netherlands & 155 & Tonga \\
\hline 27 & Cambodia & 70 & Indonesia & 113 & New Zealand & 156 & Trinidad and Tobago \\
\hline 28 & Cameroon & 71 & Iran & 114 & Niger & 157 & Tunisia \\
\hline 29 & Canada & 72 & Iraq & 115 & Nigeria & 158 & Turkey \\
\hline 30 & Cape Verde & 73 & Ireland & 116 & North Korea & 159 & Turkmenistan \\
\hline 31 & $\begin{array}{l}\text { Central African } \\
\text { Republic }\end{array}$ & 74 & Israel & 117 & Norway & 160 & Uganda \\
\hline 32 & Chad & 75 & Italy & 118 & Oman & 161 & Ukraine \\
\hline 33 & Chile & 76 & Jamaica & 119 & Pakistan & 162 & United Arab Emirates \\
\hline 34 & Colombia & 77 & Japan & 120 & Palau & 163 & United Kingdom \\
\hline 35 & Comoros & 78 & Jordan & 121 & Panama & 164 & United States \\
\hline 36 & Congo & 79 & Kazakhstan & 122 & $\begin{array}{l}\text { Papua New } \\
\text { Guinea }\end{array}$ & 165 & Uruguay \\
\hline 37 & Congo DR & 80 & Kenya & 123 & Paraguay & 166 & Uzbekistan \\
\hline 38 & Côte d'Ivoire & 81 & Kuwait & 124 & Philippines & 167 & Vanuatu \\
\hline
\end{tabular}




\begin{tabular}{|c|c|c|c|c|c|c|c|}
\hline 39 & Croatia & 82 & Kyrgyz & 125 & Poland & 168 & Venezuela \\
\hline 40 & Cuba & 83 & Laos & 126 & Portugal & 169 & Vietnam \\
\hline 41 & Cyprus & 84 & Latvia & 127 & Qatar & 170 & Yemen \\
\hline 42 & Czech & 85 & Lebanon & 128 & Romania & 171 & Zambia \\
\hline 43 & Denmark & 86 & Lesotho & 129 & Russia & 172 & Zimbabwe \\
\hline
\end{tabular}




\begin{tabular}{|c|c|c|c|c|c|c|c|c|c|c|c|c|}
\hline \multirow{3}{*}{$\begin{array}{l}\text { Dependen } \\
\text { t: }\end{array}$} & \multicolumn{6}{|c|}{ OLS } & \multicolumn{6}{|c|}{ FE } \\
\hline & \multicolumn{2}{|c|}{ Technology } & \multicolumn{2}{|c|}{ Natural resources } & \multicolumn{2}{|c|}{ Income level } & \multicolumn{2}{|c|}{ Technology } & \multicolumn{2}{|c|}{ Natural resources } & \multicolumn{2}{|c|}{ Income level } \\
\hline & (1) & $(2)$ & (3) & $\begin{array}{l}(4) \\
\text { Less }\end{array}$ & (5) & (6) & (7) & $(8)$ & (9) & $\begin{array}{l}\text { (10) } \\
\text { Less }\end{array}$ & (11) & (12) \\
\hline $\begin{array}{l}\operatorname{lnCOFDI} \\
\mathrm{S}\end{array}$ & High & Low & $\begin{array}{c}\text { Abunda } \\
\text { nt }\end{array}$ & $\begin{array}{c}\text { Abunda } \\
\text { nt }\end{array}$ & High & Low & High & Low & $\begin{array}{c}\text { Abunda } \\
\text { nt }\end{array}$ & $\begin{array}{c}\text { Abunda } \\
\text { nt }\end{array}$ & High & Low \\
\hline $\begin{array}{l}\operatorname{lnCOFDI} \\
\mathrm{S}_{\mathrm{t}-1}\end{array}$ & $\begin{array}{c}0.819 * * \\
* \\
(0.043)\end{array}$ & $\begin{array}{c}0.755 * * \\
* \\
(0.055)\end{array}$ & $\begin{array}{c}0.688 * * \\
* \\
(0.055)\end{array}$ & $\begin{array}{c}0.843 * * \\
* \\
(0.046)\end{array}$ & $\begin{array}{c}0.791 * * \\
* \\
(0.045)\end{array}$ & $\begin{array}{c}0.693 * * \\
* \\
(0.072)\end{array}$ & $\begin{array}{c}0.383 * * \\
* \\
(0.133)\end{array}$ & $\begin{array}{c}0.258 * * \\
* \\
(0.094)\end{array}$ & $\begin{array}{c}0.202 * * \\
* \\
(0.069)\end{array}$ & $\begin{array}{c}0.461 * * \\
* \\
(0.133)\end{array}$ & $\begin{array}{c}0.352 * * \\
* \\
(0.098)\end{array}$ & $\begin{array}{c}0.188^{*} \\
* \\
(0.084)\end{array}$ \\
\hline $\operatorname{lnCIFDIS}_{t}$ & $\begin{array}{c}0.096 * * \\
* \\
(0.036)\end{array}$ & $\begin{array}{c}0.070 * * \\
* \\
(0.022)\end{array}$ & $\begin{array}{c}0.041 \\
(0.029)\end{array}$ & $\begin{array}{c}0.034 \\
(0.027)\end{array}$ & $\begin{array}{c}0.121 * * \\
* \\
(0.032)\end{array}$ & $\begin{array}{c}0.029 \\
(0.022)\end{array}$ & $\begin{array}{l}-0.053 \\
(0.113)\end{array}$ & $\begin{array}{l}-0.004 \\
(0.075)\end{array}$ & $\begin{array}{c}-0.101 * \\
(0.054)\end{array}$ & $\begin{array}{c}0.097 \\
(0.120)\end{array}$ & $\begin{array}{c}-0.098 \\
(0.159)\end{array}$ & $\begin{array}{c}0.021 \\
(0.051)\end{array}$ \\
\hline $\begin{array}{l}\text { Country } \\
\text { dummy } \\
\text { Year } \\
\text { dummy } \\
\text { Control } \\
\text { variables }\end{array}$ & Yes & Yes & Yes & Yes & Yes & Yes & Yes & Yes & Yes & Yes & Yes & Yes \\
\hline
\end{tabular}

Notes: *significant at $10 \% ; * *$ significant at $5 \%$; and *** significant at $1 \%$; robust standard errors in parentheses. Please see Appendix A for variable definitions. 